\title{
The New (ab)Normal in American Politics
}

\author{
Michael Bernhard and Daniel I. O'Neill
}

\section{American Politics Unbound}

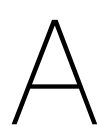
large part of this issue is devoted to a special section entitled "The New (ab)Normal in American Politics." Politics in the United States was long seen by many as highly institutionalized and stable. And the field of American Politics developed a series of influential theories and an elaborate battery of methods to study that normalcy. From this perspective, American politics was not unlike that of many other advanced industrial countries in the immediate postwar period. The period from approximately 1945 to 1975 , dubbed les Trente Glorieuses (the glorious thirty) by the French economist Jean Fourastie, ${ }^{1}$ was one of unprecedented growth and increasing political inclusion in the West. The prosperity of these years was in no small measure due to the willingness of the United States to establish and support a global liberal order, something it had failed to do in the interwar period. ${ }^{2}$

Both Thomas Piketty and Barry Eichengreen have argued that this thirty year period was quite exceptional in terms of economic performance. After the severe contraction and slow recovery associated with the Great Depression, and the devastation caused by the Second World War, recovery was followed by a period of robust growth where sustained per capita growth rates of four percent per year were not unusual. ${ }^{3}$ As we know from the experience of the developing world, periods of expansive economic growth provide new opportunities to incorporate previously excluded socio-economic groups, ${ }^{4}$ or as the school of rational distributionists has put it: democracy becomes more likely as the bargaining space between actors with conflicting interests narrows due to increased wealth. ${ }^{5}$ Sheri Berman has argued that the unprecedented prosperity of this period was the thing that allowed democracy to firmly establish itself in continental Europe by enabling the building of more expansive welfare states and finally overcoming deeply antagonistic class divisions. ${ }^{6}$

During the same period, the United States also benefitted from expansive growth, a more generous welfare state, and an ideological consensus among elites where it was relatively easy to accommodate the conflicting goals of established contending interests. ${ }^{7}$ Such an establishment consensus initially led some observers to declare the "end of ideology" in America. ${ }^{8}$ The critics, however, were quick to point out that the American system certainly privileged the organized over individuals, and favored big business in ways that allowed it to circumvent polyarchic controls in defense of their interests. ${ }^{10}$ Moreover, and even despite the bias towards the wealthy and against African Americans, other ethnic outsiders, LGBTQ citizens, and women, late in this period of prosperity new social movements representing formerly excluded groups emerged and fought for their place at the table as free and equal citizens. ${ }^{11}$ The struggles in the 1960s over civil rights, women's rights, and in opposition to the war in Vietnam challenged the status quo. They also revealed the extent to which "ascriptive Americanism" based on race, gender, and ethnic hierarchies has been a defining feature of the country since its inception. From this standpoint, "liberal democracy" in America looked far less like the historical inevitability depicted by Louis Hartz, and far more like an uncertain and incomplete project born of battles between multiple competing traditions in American political thought. ${ }^{12}$ Ultimately, these struggles transformed but did not overturn the system.

Against this backdrop, sustained expansion came abruptly to a halt in the 1970s, precipitated by oil shocks triggered by another Arab-Israeli war (1973) and the Iranian Revolution (1979). While there is debate over the extent to which the slowdown was caused by petroleum prices, it was at least exacerbated by the disruption in energy supplies. Western prosperity and its associated politics were in part predicated on a plentiful and cheap supply of raw materials including petroleum, and the global increase in commodity prices that followed required extensive adaptation to a new reality in which cost push inflation diminished effective demand, and coincided with stagnation in productivity. ${ }^{13}$ Since the 1970s, Western economic growth has reverted to the slower pace expected in developed economies, ${ }^{14}$ to around one to two percent a year.

With slow growth, distributional politics in America has become a zero-sum game, and our ability to compromise has been curtailed by the ideological realignment of our party system following the consolidation 
of electoral hegemony in the South by the Republicans since 1980. ${ }^{15}$ While the tools and methods developed by Americanists to analyze our politics have proved robust, the theoretical assumptions that underlie our understanding of American politics have changed. If we ever could, we can certainly no longer assume compromise, expansive economic growth, centripetal competition and its moderating effects, the desire for greater political inclusion, and strongly institutionalized norms and practices. Instead, American politics has grown more contentious, its rhetoric more confrontational, and American society more compartmentalized and polarized. The notion that America is the leading democracy either in a global politics sense, as outlined in David Lake's presidential address this year, ${ }^{16}$ or in terms of its domestic democratic performance, ${ }^{17}$ are far from evident at this point. And this all seems to be accelerating since the onset of the Great Recession of 2008.

We raise these developments, not because as a comparativist and a theorist, we want to chastise our Americanist colleagues, but instead to celebrate how the field has responded to these challenges. The field of American politics has become all the more exciting because a changing landscape unveils new problems, new research questions, and innovative theory and methods to cope with that changed environment. In reading a large number of submissions in American politics, it strikes us that the subfield is in a highly innovative phase. It also seems quite open to influence from other subfields which have confronted domestic political environments of this sort, particularly comparative politics.

The articles that constitute "The New (ab)Normal in American Politics" are illustrative of the flourishing of the subfield of American Politics in the face of our new political reality. The first two articles explore these themes through the prism of the controversies surrounding the Affordable Care Act (ACA), the signature achievement of the Obama presidency, now under attack by the unified executive and legislative power of the Republicans. Jan Leighley and Jennifer Oser assess the relative effects of popular mobilization and unequal material resources on political outcomes. The takeaway of "Representation in an Era of Political and Economic Inequality: How and When Citizen Engagement Matters" is that citizens with fewer resources can still effectively influence their representatives through political engagement outside the electoral arena.

Lawrence Jacobs and Suzanne Mettler investigate the degree to which Schattschneider's observation "that a new policy creates a new politics" holds today. Using public opinion data on responses to ACA, in "When and How New Policy Creates New Politics: Examining the Feedback Effects of the Affordable Care Act on Public Opinion," they examine what explains the degree of political feedback generated by policy change, as well as the nature of that change. They highlight how a range of factors, including partisanship, trust, policy design, and new burdens, mediate and shape feedback effects. In the back half of the journal, Scott Greer also considers a number of issues surrounding the ACA in his Review Essay of three recent books on the American healthcare system in "The Politics of Bad Policy in the United States."

Alexander Hertel-Fernandez also explores policy feedback in "Policy Feedback as Political Weapon: Conservative Advocacy and the Demobilization of the Public Sector Labor Movement." In his account new policies are designed not only to enhance the position of supporters, but to also deny resources and support to disarm one's opponents. He explores this by looking at new state-level legislation on public service unions and shows that concerted action by conservative policy networks has diminished union revenue and membership. In this sense policy becomes more than an approach to solving problems but also a means to solidify the hold on power of the policymakers.

Margaret Weir and Jessica Schirmer explore the bifurcation of the American welfare regime in "America's Two Worlds of Welfare: Subnational Institutions and Social Assistance in Metropolitan America." They show that the delegation of welfare functions by the federal government to the states has led to two different welfare state systems - a civic-public model which is more prominent in the cities of the Northeast and the Midwest and a religious-private model in the South and Mountain West. Given the shift of population to the latter two areas, the prospects for the poor in the contemporary era are not auspicious.

In "Black Lives Matter: Evidence that Police-Caused Deaths Predict Protest Activity," Vanessa Williamson, Kris-Stella Trump, and Katherine Levine Einstein return to the theme of the carceral state and its impact on contentious politics. They find that the activism of Black Lives Matter is a product of local conditions, specifically that the protest movement emerged in 2014-2015 in areas where more African Americans had been killed previously by the police. This shows that harsher forms of repression by the carceral state do not discourage civic participation, but in contrast, provoke intense defensive mobilization. Black Lives Matter is also taken up in a Review Essay by Derrick Darby, "Democracy Born of Struggle." Darby reviews Christopher Lebron's new book on the movement, together with books by Alex Zamalin on African American political thought, and Sharon Stanley on racial integration in the United States.

Finally, in a reflection on "Racial Identity and Voting: Conceptualizing White Identity in Spatial Terms" Nicholas Weller and Jane June examine the role of race in voting choices using a rational choice framework. In conceiving of whiteness as a form of privilege that conveys a utility payoff in the preferences of some voters, they frame the choice to vote against their redistributive 
interests in a two-good dimensional space. Its novelty lies in not seeing racial voting as "irrational" or "deeply cultural" by taking seriously the assertion that whiteness is a real privilege in a society with a long history of racism. It holds out the prospect of explaining the paradox of why some voters choose to vote against their material interests under such circumstances.

\section{Other Content in this Issue}

Finally, Nicolas Jabko and Adam Sheingate add to the institutionalist literature by probing the ability of dysfunctional institutions to persist in "Practices of Dynamic Order." Aligning themselves with the neo-pragmatic school of institutionalists they focus on microadjustments to rules and procedures by actors in power in order to stabilize order in times of crisis. The logic of regenerating order is illustrated by a discussion of the Eurozone crisis and the precariousness of state authority in the United States as reflected in the uprising in Baltimore in April-May 2015 following the death of Freddie Grey.

\section{Transparency}

Perspectives was one of the major journals not to sign the Journal Editors' Transparency Statement (JETS). While the former editor and the board were highly supportive of research transparency and replicability, there was extensive concern over whether DART and JETS had a one-size-fitsall notion of research and how to implement transparency. The present editorial staff shares these concerns, and is interested in promoting data transparency and the replicability of work where it is appropriate.

To this end, the Perspectives on Politics Dataverse came on line for the articles publish in issue 16(1). The authors of quantitative work are now posting replication files there. With regards to qualitative work we are being more cautious in terms of implementing universal standards for data and inferential transparency. We are actively working with individual scholars to cultivate new ways of doing this, and are encouraging them to use online appendices, so as not to crowd out substantive content in the body of the journal itself. There are qualitative articles in the pipeline that will make use of the Syracuse Qualitative Data Repository and we are exploring possibilities regarding active citation.

We are also in the process of studying the replication and transparency statements of other major journals so as to update the online "Statement on Scholarly Recognition" for Perspectives. In coming issues we will also be publishing a series of reflections on transparency exploring the diverse perspectives raised in the Qualitative Transparency Deliberations. ${ }^{18}$

\section{Final Note}

Perspectives activated Publons last month. ${ }^{19}$ For those unaware, it is an app embedded in Editorial Manager that allows our manuscript reviewers to take credit for their reports and keep an ongoing record of their service to the profession in this sphere. Perspectives, as a general interest journal, relies heavily on the knowledge of its reviewers. We use a minimum of four readers on the first review. The quality of our readers' reports are generally high, leading to improvements in the innovativeness and clarity of our articles. We realize that providing a public record of the service of reviewers is small compensation for the kind of work you do. We appreciate your centrality to the success of the journal.

\section{Notes}

1 Fourastié 1979.

2 Tooze 2014.

3 Piketty 2014, 87; Eichengreen 2008, 89-93.

4 O'Donnell 1973, 135.

5 Przeworski 2005, 264.

6 Berman 2012, 8-9.

7 Lowi 1979, 50-51.

8 Bell 1960.

9 Schattschneider 1960, 31.

10 Lindblom 1977, 170-188.

11 Inglehardt 1977, 16.

12 Smith 1993.

13 Eichengreen 2008, 30.

14 Barro 1999, 1-2.

15 Black and Black 2005, 205-6.

16 Lake 2018.

17 Azpuro and Hall 2018. Curiously, the authors of this piece did not consult the democracy scores of the Varieties of Democracy project, which has consistently rated American democracy as far from exemplary.

18 https://www.qualtd.net/\#.

19 https://publons.com/home/.

\section{References}

Azpuro, Dinorah and Michael Hall. 2017. "Yes, Our 'Flawed' Democracy Just Got Downgraded. Here's Why." Washington Post (February 23, 2017), accessed February 8, 2018. https://www.washingtonpost.com/ news/monkey-cage/wp/2017/02/23/yes-our-flaweddemocracy-just-got-downgraded-heres-why/? utm_term $=$. a3186d0f814d.

Bell, Daniel. 1962. The End of Ideology: On the Exhaustion of Political Ideas in the Fifties. Cambridge, MA: Harvard University Press.

Black, Earl and Merle Black. 2002. The Rise of Southern Republicans. Cambridge, MA: Harvard University Press.

Barro, Robert J. 1999. Determinants of Economic Growth: A Cross-Country Empirical Study. Cambridge, MA: MIT Press.

Berman, Sheri. 2012. "Warnings from History." Journal of Democracy 23(4): 7-14.

Eichengreen, Barry. 2008. The European Economy since 1945: Coordinated Capitalism and Beyond. Princeton, NJ: Princeton University Press. 
Fourastié, Jean. 1979. Les Trente Glorieuses ou la Révolution Invisible de 1946 à 1975. Paris: Fayard.

Inglehart, Ronald. 1977. The Silent Revolution. Princeton, NJ: Princeton University Press.

Lindblom, Robert. 1977. Politics and Markets. New York: Basic Books.

Lake, David A. 2018. "International Legitimacy Lost? Rule and Resistance When America Is First." Perspectives on Politics 16(1): 6-21.

Lowi, Theodore. 1979. The End of Liberalism: The Second Republic of the United States. 2nd ed. New York: Norton.

O'Donnell, Guillermo. 1973. Modernization and Bureaucratic-Authoritarianism: Studies in South American Politics. Berkeley: Institute of International Studies, University of California.
Piketty, Thomas. 2014. Capital in the Twenty-First Century. Cambridge, MA: Belknap Press.

Przeworski, Adam. 2005. "Democracy as an Equilibrium." Public Choice 123(3-4): 253-73.

Schattschneider, Elmer Eric. 1960. The Semi-Sovereign People: A Realist's View of Democracy in America. New York: Holt, Reinhardt, and Winston.

Smith, Rogers M. 1993. "Beyond Tocqueville, Myrdal, and Hartz: The Multiple Traditions in America." American Political Science Review 87(3): 549-66.

Tooze, Adam. 2014. The Deluge: The Great War, America and the Remaking of the Global Order. New York: Penguin. 


\section{Statement of Mission and Procedures}

Perspectives on Politics seeks to provide a space for broad and synthetic discussion within the political science profession and between the profession and the broader scholarly and reading publics. Such discussion necessarily draws on and contributes to the scholarship published in the more specialized journals that dominate our discipline. At the same time, Perspectives seeks to promote a complementary form of broad public discussion and synergistic understanding within the profession that isessential toadvancing scholarship and promoting academic community.

Perspectives seeks to nurture a political science public sphere, publicizing important scholarly topics, ideas, and innovations, linking scholarly authors and readers, and promoting broad reflexive discussion among political scientists about the work that we do and why this work matters.

Perspectives publishes work in a number of formats that mirror the ways that political scientists actually write:

Research articles: As a top-tier journal of political science, Perspectives accepts scholarly research article submissions and publishes the very best submissions that make it through our double-blind system of peer review and revision. The only thing that differentiates Perspectives research articles from other peer-reviewed articles at top journals is that we focus our attention only on work that in some way bridges subfield and methodological divides, and tries to address a broad readership of political scientists about matters of consequence. This typically means that the excellent articles we publish have been extensively revised in sustained dialogue with the editor-me-to address not simply questions of scholarship but questions of intellectual breadth and readability.

"Reflections" are more reflexive, provocative, or programmatic essays that address important political science questions in interesting ways but are not necessarily as systematic and focused as research articles. These essays often originate as research article submissions, though sometimes they derive from proposals developed in consultation with the editor in chief. Unlike research articles, these essays are not evaluated according to a strict, doubleblind peer review process. But they are typically vetted informally with editorial board members or other colleagues, and they are always subjected to critical assessment and careful line-editing by the editor and editorial staff.

Scholarly symposia, critical book dialogues, book review essays, and conventional book reviews are developed and commissioned by the editor in chief, based on authorial queries and ideas, editorial board suggestions, and staff conversations.

Everything published in Perspectives is carefully vetted and edited. Given our distinctive mission, we work hard to use our range of formats to organize interesting conversations about important issues and events, and to call attention to certain broad themes beyond our profession's normal subfield categories.

For further details on writing formats and submission guidelines, see our website at http://www.apsanet.org/ perspectives/ 